\title{
1 Guidance for Investigating Calcite Precipitation by Urea Hydrolysis for Geomaterials
}

3

$33{ }^{1}$ Research scholar, Department of Civil Engineering, Indian Institute of Technology Bombay,

34 Powai, Mumbai-400076, India, bs_shashank@yahoo.co.in

$35{ }^{2}$ Research Associate, Department of Civil and Environmental Engineering, University of 36 Strathclyde, Glasgow- G1 1XJ, UK, james.minto@strath.ac.uk

$37{ }^{3}$ Professor, Department of Civil Engineering, Indian Institute of Technology Bombay, Powai, 38 Mumbai-400076, India, dns@civil.iitb.ac.in

$39{ }^{4}$ Lecturer, Department of Civil and Environmental Engineering, University of Strathclyde, 40 Glasgow- G1 1XJ, UK, grainne.elmountassir@strath.ac.uk

$41{ }^{5}$ Senior Lecturer, Department of Civil and Environmental Engineering, University of 42 Strathclyde, Glasgow- G1 1XJ, UK, charles.knapp@strath.ac.uk

$43{ }^{*}$ Corresponding author, Tel.: +91-22-2576-7340; Fax: +91-22-2576-7302. 44 


\section{$1 \quad$ Abstract}

2 Microbially Induced Calcite Precipitation (MICP) is a sustainable method of stabilizing (i.e., 3 cementing) loose sandy deposits and/or to create an impervious barrier within the soil mass.

4 MICP can occur through various biochemical pathways, among which 'Urea Hydrolysis

5 (UH)' is considered to be the most efficient method of biochemically inducing calcite 6 precipitation. To date, the geotechnical engineering community investigating MICP has

7 tended to focus on the hydro-mechanical behaviour of the end product, i.e. MICP cemented 8 sands; however, many biochemical factors that affect reaction-rate kinetics and MICP 9 outcome have been understudied or neglected. This study investigated the kinetics of UH and 10 compared different sources of urease enzyme: those microbially cultivated in the laboratory 11 (i.e., Sporosarcina pasteurii) and those extracted from plants (i.e., Jack bean meal), to 12 investigate the influence of urea concentration, buffer capacity, and cell harvesting method on 13 UH. Through this study, an attempt has been made to arrive at an optimal concentration of 14 urea, under the influence of the above mentioned parameters along with the buffering action 15 of the soil, on urea hydrolysis. These results have implications towards optimising MICP and, 16 in particular, for upscaling these methods to in-situ applications.

17 Keywords: soil stabilization, ground improvement, microbial activity, ureolytic activity, urea 18 hydrolysis, calcite precipitation. 


\section{Introduction}

2 For most civil engineering projects, in-situ soil conditions must meet the necessary

3 technical (engineering or functional) requirements; as such, various ground improvement

4 techniques mainly based on mechanical, chemical, thermal and vacuum treatments, either

5 individually or involving a combination of techniques are employed. Such techniques include

6 consolidation by preloading, vacuum assisted pre-consolidation, thermal treatment,

7 stone/sand columns, excavation and replacement [1], dynamic compaction by heavy tamping

8 [2], vibro-flotation [3] and deep mixing [4]. These techniques often consume large quantities

9 of natural resources (i.e., soils, sands, weathered rocks, stones and lime) and/or manmade

10 resources (i.e., cement, admixtures and chemicals), which can be both expensive and

11 damaging to the environment to extract, produce and transport to project sites[5]. Hence,

12 there is a need for alternative ground improvement techniques that are sustainable and satisfy

13 performance expectations, and minimise environmental impact.

14 Biotechnology may offer such a technique through the process of biologically induced

15 mineralisation wherein organisms secrete metabolites in their external environment, which in 16 turn, react with ions or compounds to precipitate extracellular mineral phases [6]. One such

17 'bio-mineralisation' of interest to civil engineers is the microbially induced precipitation of 18 calcium carbonate by urea hydrolysis by $\mathrm{UH}$, having been proposed for use in bio-concrete, 19 self-sealing and self-healing concrete, safeguarding heritage structures, mitigation of dust in 20 construction sites [7;8], and in particular, for ground improvement (see Table 1). 21 Interestingly, all these studies considered coarse-grained materials (i.e., sands) due to the 22 physical limitations associated with the migration of micro-organisms through the pores of 23 fine-grained soils (i.e., those clayey and silty). For the application of microbially induced 24 calcite precipitation (MICP) to finer-grained soils it is necessary to consider alternative 
1 sources of urease enzyme (such as a plant source), as the urease enzyme is around $12 \mathrm{~nm}$ in

2 size compared to a few microns for the whole-cell of S. pasteurii.

3 Furthermore the effectiveness of MICP treatment (described in Section 2 below)

4 depends on (1) biochemical factors which affect the kinetics of UH, and (2) the

5 soil/geomaterial specific parameters (i.e., porosity, particle size distribution, sorption

6 properties, etc.). However, the optimal conditions/mix proportions of cementing reagents

7 (i.e., urea and $\mathrm{CaCl}_{2}$ ) reported in the previous studies (refer Table 1) for efficient MICP have

8 been based on the improvement in engineering properties of the treated materials alone, and

9 do not consider the kinetics of UH. The authors are of the opinion that engineers should seek

10 to optimize the biochemical aspects and its influence on engineering behaviour of

11 geomaterials, in order to select appropriate conditions for upscaling the growth and

12 preparation of treatment fluids for in-situ applications.

13 This study aims to provide a fundamental understanding of the microbiological and 14 biochemical influences on the kinetics of urea hydrolysis so that UH-based calcite 15 precipitation may be optimized and better controlled. This is achieved through systematic 16 investigation of the following: (1) bacterial cell harvesting method, (2) urea (substrate) 17 concentration, (3) bacterial growth (nutrient) medium, (4) source of urease enzyme-microbial 18 (Sporosarcina pasteurii) and plant (Jack bean meal extracts), and (5) $\mathrm{pH}$ in the presence of 19 buffer medium.

20 Calcite Precipitation by Urea Hydrolysis

21 Enzymatic urea hydrolysis can be summarised by the following two chemical reactions 22 [9]:

$$
\begin{gathered}
\mathrm{CO}\left(\mathrm{NH}_{2}\right)_{2}+2 \mathrm{H}_{2} \mathrm{O} \stackrel{\text { Urease }}{\longrightarrow} \mathrm{CO}_{3}^{2-}+2 \mathrm{NH}_{4}^{+} \\
\mathrm{CO}_{3}^{2-}+\mathrm{Ca}^{2+} \rightarrow \mathrm{CaCO}_{3} \downarrow
\end{gathered}
$$


1 Urea (the substrate) is hydrolysed into ammonium $\left(\mathrm{NH}^{4+}\right)$ and carbonate $\left(\mathrm{CO}_{3}{ }^{2-}\right)$ ions

2 (reaction product) by utilising two molecules of water $\left(\mathrm{H}_{2} \mathrm{O}\right)$ in the presence of urease

3 enzyme, which catalyses the reaction. The hydrolysis progresses with time and depends on

4 the concentration of urea $\left(\mathrm{C}_{\text {urea }}\right)$ and the urease enzyme $\left(\mathrm{C}_{\text {urease }}\right)$ in the system at any instant of

5 time (t) and the rate of urea hydrolysis (UH). The hydrolysis of urea tends to increase the $\mathrm{pH}$

6 of the bulk fluid and once the buffer capacity of the UHM is reached, $\mathrm{pH}$ increases. As the

$7 \mathrm{pH}$ approaches 9, calcium carbonate precipitates. Although a rise in $\mathrm{pH}$ is desirable and

8 necessary, an instantaneous increase may not be preferred during its implementation in the

9 field as this can lead to clogging of the soil matrix near the injection or inlet point by the

10 rapid precipitation of calcium carbonate. This, in turn, restricts the extent of ground

11 improvement around of the inlet point. However, a prolonged delay in precipitation might

12 result in excess volumes of treatment fluids being injected into the soil matrix leading to

13 increased costs as well as influencing the ground conditions in adjacent locations where the

14 treatment is not mandated. Without proper optimisation, both of these situations could be 15 detrimental in obtaining the desired results. Hence, in order to overcome this situation, 16 controlling the time required for precipitation by regulating $\mathrm{pH}$ using a suitable buffer, which

17 does not interfere either with the activity of the cells or with the reaction process, may be 18 necessary. Previous researchers have attempted MICP by employing a combination of $19 \mathrm{NaHCO}_{3}$ and $\mathrm{NH}_{4} \mathrm{Cl}$ as a buffer (e.g. [10], [11]). However, it should be noted that prior to the 20 introduction of urease enzyme in to the soil (either microbial or plant based form), $\mathrm{NaHCO}_{3}$ 21 and $\mathrm{Ca}^{2+}$ will react abiotically to form $\mathrm{CaCO}_{3}$. This undesirable utilisation of calcium leads to 22 reduced availability of calcium for MICP and the increased risk of clogging of soil pores 23 during the injection stage. 
1 bean is one of the most widely studied enzyme sources [12-15]. On the other hand,

2 microorganisms such as Sporosarcina pasteurii, Sporosarcina aquamarina, Bacillus subtillis,

3 Sporosarcina ureae etc. are known to be good sources of urease enzyme. The most widely

4 used microorganism for calcite precipitation is S. pasteurii [13]. The enzyme from plants

5 could be derived through their leaves and seeds, while the microorganisms secrete

6 extracellular urease enzyme. Microbial cells need to be separated from the nutrient medium

7 in which they were inoculated, commonly referred to as 'cell harvest', in order to avoid

8 contamination of geoenvironment by these nutrient media. Different harvest methods affect

9 cell yields and the sustenance of urease activity. Shear stresses, due to centrifugation or

10 filtration, could lead to cell lysis, and hence, necessitate culturing larger volumes of microbial

11 cells leading to an increased consumption of nutrient medium and increased cost of cell

12 cultivation. Hence, the influence of cell harvest on the enzyme kinetics has also been

13 investigated in this study, for the sake of completeness.

\section{Experimental Investigations}

15 The materials used and the process adopted in this study are depicted in Fig. 1 and 16 described in the following sections.

\section{SOURCE OF UREASE ENZYME}

18 In this study, urease enzyme from two different sources were used: (i) microbial source

19 (Sporosarcina pasteurii, DSM-33, procured from Deutsche Sammlung von Mikroorganismen

20 und Zellkulturen, DSMZ, Germany) and (ii) plant source (urease-enzyme crude extract from

21 Jack bean meal plant; Fisher Scientific Ltd., UK).

22 UREA (SUBSTRATE) AND BUFFER MEDIUM

23 Urea (99.9\% purity, Fisher Scientific Ltd., UK) was used in the present study.

24 Different buffers investigated include: (i) phosphate buffered saline (PBS), (ii) sodium

25 bicarbonate/ ammonium chloride $\left(2.12 \mathrm{~g} / 1 \mathrm{NaHCO}_{3}+10 \mathrm{~g} / \mathrm{l} \mathrm{NH} 4 \mathrm{Cl}\right)$, (iii) Tris buffer 
1 cytoplasm, to maintain cell survival and activity. In case of jack bean meal, extracts of

2 different concentrations were tested to identify a concentration that corresponded to similar

3 urease activity as that of Sporosarcina pasteurii cells at $\mathrm{OD}_{600}$ of 1.0 , and $2.7 \mathrm{~g} / 1$ was found

4 to be equivalent.

\section{$5 \quad$ Ureolytic activity}

$6 \quad$ Ureolytic activity in the UHM was determined based on the concentration of products

7 formed and was determined through by measurement of electrical conductivity (EC) of the

8 mixture at various time intervals for up to 60 minutes. As urea is hydrolysed, increase in EC

9 of the UHM is directly proportional to the concentration of UH reaction products (see Eq. 1).

10 By plotting the rates of urea hydrolysis (i.e., electrical conductivity change) against different

11 concentrations of urea, the optimal concentration of urea, i.e., the concentration of urea

12 beyond which had no further increase in rate of $\mathrm{UH}$, could be identified.

13 However, due to the presence of calcium in the system, PBS cannot be used as a

14 buffer medium during calcite precipitation owing to the affinity of calcium towards

15 phosphate, which results in the formation of calcium phosphate instead of calcium carbonate.

16 Hence, PBS is an indicator of ideal conditions for optimal ureolytic activity and not

17 considered here as a suitable buffer for use in the full MICP process. Further, in order to

18 verify the buffer's influence on the UH, the activity of the urease enzyme in different buffers,

19 at the previously optimised substrate concentration, was also studied and compared.

\section{Substrate-Dependent Enzyme Kinetics}

21 To fully understand enzyme kinetics over a wide range of substrate conditions.

22 Enzyme-mediated transformations were monitored over time to calculate reaction rates

$23\left(\mathrm{R}_{\mathrm{UH}}\right)$; from a series of reaction rates (per substrate concentration, [S]), a Michaelis-Menten

24 model represented in Eq.3 was developed by Johnson and Goody [16]. 


$$
\begin{gathered}
R_{U H}=\frac{R_{U H m}[S]}{k_{m}+[S]} \\
\frac{1}{R_{U H}}=\frac{k_{m}}{R_{U H m}} \times \frac{1}{[S]}+\frac{1}{R_{U H m}}
\end{gathered}
$$

1 The maximum rates (typically $\mathrm{V}_{\max }$, here we use ' $\mathrm{R}_{\mathrm{UHm}}$ ') and the Michaelis-Menten constant

$2\left(\mathrm{k}_{\mathrm{m}}\right)$, which is the concentration of the substrate required to produce half the maximum rate of

3 the reaction, are the primary parameters defining the Michaelis-Menten model; they are

4 calculated from Lineweaver Burk transformations (Fig. 4), which becomes a plot of $1 / \mathrm{R}_{U H} \mathrm{~V} / \mathrm{s}$

$5 \quad 1 /[S]$ and represented in the Eq. 4. By doing so, the Michaelis-Menten plot of $\mathrm{R}_{\mathrm{UH}} \mathrm{v} / \mathrm{s}$ [S] is

6 linearised; the intercept on $\mathrm{y}$-axis becomes $1 / \mathrm{R}_{\mathrm{UHm}}$, and the intercept on $\mathrm{x}$-axis becomes -

$7 \quad 1 / k_{\mathrm{m}}$. Although enzyme-substrate affinities (i.e., often represented by $\mathrm{k}_{\mathrm{m}}$ ) are not likely to be

8 affected for a given combination of substrate and enzyme, $\mathrm{k}_{\mathrm{m}}$ is presented in this study as a

9 model parameter to help define the shape of the model curve. As such, the Michaelis-Menten

10 model has been utilised to compare enzyme reactions.

\section{Selection of buffer medium}

12 The harvested cells, as discussed previously, were re-suspended in different buffer 13 solutions and in sterilised tap water (as control); the $\mathrm{OD}_{600}$ was adjusted to 1.0. Optimal 14 concentration of urea, as derived through the process described in the previous section, was 15 dissolved in different buffer media and $\mathrm{pH}$ of the system was monitored either for 60 minutes 16 or until it reached $\mathrm{pH} 8.5$. This was investigated to determine the selection of an appropriate 17 buffer medium that would result in delayed calcite precipitation, which during in-situ practice 18 could facilitate the distribution of solutions by increasing the time allowed for the 19 reagents/grouts to flow through the pores.

\section{Buffering capacity of soil}

21 Whenever soil mass and a fluid interacts with each other, the $\mathrm{pH}$ of the fluid will be affected 22 by its buffering action. As such, when UH is being implemented in the field, knowing the 
1 buffering capacity of the soil mass is critical. To ascertain the effects of buffering action, five

2 different soils whose $\mathrm{pH}$ ranges from 6.5 to 7.5 were considered in the study. These soils

3 were interacted with de-ionised water for 24 hours and the supernatant was extracted by

4 filtration. Further, the optimal concentration of urea derived through the process discussed

5 previously), was dissolved in the supernatant and $\mathrm{pH}$ was monitored by adopting the

6 methodology described for selection of buffer medium.

\section{$7 \quad$ Results and Discussions}

\section{CELL HARVEST}

9 The microbial cells harvested by centrifugation were re-suspended in buffer medium, 10 and the $\mathrm{OD}_{600}$ of this suspension was adjusted by to 1.0 . The total volume of the cultures, at 11 the said concentrations, obtained was found to vary only by $\pm 1 \%$. However, filtration method 12 decreased the total number of cells due to inherent constraints associated with the method 13 (i.e., clogging of pores in the filter paper), yielding a volume $25 \%$ lower than the 14 centrifugation method. The authors believe that this reduction could be due to the stresses 15 generated on the cells during the filtration due to continuous application of vacuum. It was 16 observed that centrifugation could be completed in a much shorter duration (12 minutes) than

17 filtration, which may require 4 hours for filtration of $100 \mathrm{ml}$ of cell culture.

\section{SUBSTRATE-DEPENDENT ENZYME KINETICS}

19 The non-linear relationship between rate of $\mathrm{UH}\left(\mathrm{R}_{\mathrm{UH}}\right.$, in terms of changes in electrical 20 conductivity) with concentration of urea (substrate) were examined in the study. The 21 individual $\mathrm{R}_{\mathrm{UH}}$ (change in EC per time) are derived from Figs. 2 (a), (b), (c) and (d), which 22 shows ureolytic activity of S. pasteurii cultured in BHI and harvested by centrifugation (Fig. 23 2a), S. pasteurii cultured in BHI and harvested by filtration (Fig. 2b), S. pasteurii cultured in 24 LB (Fig. 2c), and Jack bean meal extracts (Fig. 2d). From these figures the rate of UH can be 25 derived as described in the following: 1) the slope of the straight line portion of the trends 
1 depicted in these figures represent the rate of formation of product (ammonium and

2 carbonate ions) due to enzyme activity; 2) steeper trend which represent higher rates of

3 urease activity, $\mathrm{R}_{\mathrm{UH}}$.

4 The variable reaction rates caused by harvest methods (i.e., centrifugation and filtration) for

5 S. pasteurii (cultured in BHI) is depicted in Fig. 3 (a). Similarly, Fig. 3 (b) presents the

6 variation in RUH for $S$. pasteurii cells cultivated in different media: BHI versus LB

7 (harvested at 4600x g for 8 minutes). Further, Fig. 3 (c) compares the enzymatic activity of $S$.

8 pasteurii cells (cultured in BHI and harvested by centrifugation) and that of Jack bean meal 9 extracts.

10 The trends presented in these figures indicate that $\mathrm{R}_{\mathrm{UH}}$ increases with increasing 11 concentration of urea, but eventually attains a constant rate of $\mathrm{UH}\left(\mathrm{R}_{\mathrm{UHm}}\right)$. This observation is 12 in-line with the Michaelis-Menten model of enzyme reactions, which suggests abundant 13 enzyme molecules are available at lower substrate concentrations for the reaction to proceed.

14 As the concentration of substrates increases the reaction velocity increases; however, the 15 abundance of free enzymes decrease and reaches a critical point of saturation where any 16 further increase in substrate concentration does not lead to an increase in reaction rates. At 17 this critical concentration of the substrate $\left(\mathrm{C}_{\mathrm{crt}}\right)$, the reactions are said to proceed at their 18 maximum rates $\left(\mathrm{R}_{\mathrm{UHm}}\right)$. The $\mathrm{k}_{\mathrm{m}}$ and $\mathrm{R}_{\mathrm{UHm}}$ values for all the conditions considered in the study 19 are derived from the Lineweaver-Burk transformations (as depicted in Fig. 4) and the values 20 are presented in Table 1

Figure 3 (a) compares vacuum filtration versus centrifugation cell-harvest methods, 22 and it is observed that the $\mathrm{R}_{\mathrm{UH}}$ of cells harvested by vacuum filtration appears to be higher 23 than those that were centrifuged. It is not likely that the centrifugation is affecting substrate24 enzyme affinity as the model $\mathrm{k}_{\mathrm{m}}$, is decreased by 5 -fold when centrifuged. On the other hand, $25 \mathrm{R}_{\mathrm{UHm}}$ for BHI- filtration is found to be $20 \%$ higher that BHI- centrifugation. It is noticed that 
1 the pseudo-first order reaction rates (represented by ration of $R_{U H m} / k_{m}$ ) is approximately 4

2 times higher for BHI- centrifugation as against BHI-filtration. This implies that centrifugation

3 speed of 4600x g for 8 minutes is more optimal condition than filtration (Fig. 3a). A possible

4 reason for low $\mathrm{k}_{\mathrm{m}}$ could be the built up cellular stresses during filtration, ultimately impacting

5 enzyme affinity and hence the efficiency of the UH. Furthermore, Fig. 3(a) indicates that 6 using a $\mathrm{C}_{\text {Urea }}>\mathrm{C}_{\text {crt. }}$ does not benefit in increasing urease activity.

$7 \quad$ Further, the rate of UH of $S$. pasteurii cells grown in different media as shown in Fig.

83 (b) indicates an increase in $\mathrm{k}_{\mathrm{m}}$ and reduction in $\mathrm{R}_{\mathrm{UHm}}$ when $\mathrm{LB}$ nutrient was used.

9 Consequently, the maximum rates that can be achieved in practice by using cells grown in LB

10 is less than half of that using BHI. Furthermore, the pseudo first-order rates of reaction for

11 UH by cells grown in LB is approximately $1 / 3$ of BHI- centrifugation. For such a scenario,

12 time required and efficiency for UH would be impacted.

13 In the case of Jack Bean meal (JBM) extracts, though the urease activity (measured

14 over a 5 minute period where there is an abundant supply of urea) is selected such that it is

15 comparable to that of cells grown in BHI and harvested by centrifugation, the urease curves

16 shift slightly between $\mathrm{k}_{\mathrm{m}}$ and $\mathrm{R}_{\mathrm{UHm}}$ (Fig. 3c), with $\mathrm{R}_{\mathrm{UH}}$ for $S$. pasteurii initially, at low

17 substrate concentrations, being higher, but becoming lower than JBM at high concentrations.

18 When comparing pseudo first-order rates, means rates appear twice as large for S. pasteurii

19 cells as Jack bean meal extracts. However, microbial cells provide a constant source of urease

20 enzyme (while cells are active); the urease activity can be sustained for a prolonged period.

21 Urease extracted from Jack bean meal is dissolved and freely available to encounter the 22 substrate (urea), whilst, in order for urea to be hydrolysed by bacterial urease, the urea must

23 first be transported through the microbial cell membrane and thus there is a delay evident as a

24 difference in $\mathrm{R}_{\mathrm{UHm}}$. Ultimately, S. pasteurii, when cultivated, are less expensive than 25 commercially available JBM. These factors, suggest the choice of microbial cells (i.e., $S$. 
1 pasteurii) for a sustainable and efficient calcite precipitation system, the use of sources like

2 Jack bean meal extracts would suit the treatment of soils with pore sizes comparatively

3 smaller than the bacterial cell i.e., the fine-grained soils.

4 A relative performance matrix of $\mathrm{k}_{\mathrm{m}}$ and $\mathrm{R}_{\mathrm{UHm}}$ for all the UHM conditions discussed

5 above are presented in Table 3. The relative performance of the UHM listed in the top row of

6 the matrix is compared with respect to the UHM listed in the left column of the matrix. For

7 example, in the $k_{m}$ matrix, a negative value of element $k_{m 12}$ represents the decrease in $k_{m}$ of

8 Jack bean meal extracts with respect to $S$. pasteurii cultures grown in LB nutrient medium.

9 The $\mathrm{R}_{\mathrm{UHm}}$ matrix is similar to the $\mathrm{k}_{\mathrm{m}}$ matrix in representation. The higher the negative value

10 in the $\mathrm{k}_{\mathrm{m}}$ matrix, the better the performance of the respective UHM over the other. On the

11 other hand, in $\mathrm{R}_{\mathrm{UHm}}$ matrix, the higher the positive value, the better is the performance of the

12 respective UHM over the other. With respect to $\mathrm{k}_{\mathrm{m}}$ matrix, it can observed that cultures of $S$.

13 pasteurii grown in $\mathrm{BHI}$ and harvested by centrifugation has relatively better $\mathrm{k}_{\mathrm{m}}$ by varying

14 degrees with respect to all other combinations of UHMs considered in the study. However, in

15 the case of $\mathrm{R}_{\mathrm{UHm}}$ comparison, Jack bean meal extracts perform relatively better with respect

16 to other UHMs considered in the study. In addition, a further measure of comparison between

17 the UHMs is the ratio of $\mathrm{R}_{\mathrm{UHm}}$ to $\mathrm{k}_{\mathrm{m}}$ as presented in the Table 2. The ratio of to $\mathrm{R}_{\mathrm{UHm}}$ to $\mathrm{k}_{\mathrm{m}}$ is

18 required to be higher for an efficient and economical UHM. With this criteria, it is clear that

19 S. pasteurii cultures grown in BHI nutrient medium and harvested by centrifugation are better

20 compared to all other UHMs considered. It can also be noted that the urease activity of $S$.

21 pasteurii cells, harvested by centrifugation, is greater when they are grown in BHI as compared to those grown in LB.

In order to arrive at an optimal concentration of urea for the UHMs used in a study,

25 for practical applications, authors define a critical concentration of the urea $\left(\mathrm{C}_{\mathrm{Crt}}\right)$, beyond 
1 which the $\mathrm{R}_{\mathrm{UH}}$ does not change more than $15 \%$. In other words, $\mathrm{C}_{\mathrm{Crt}}$ is that concentration of

2 urea which produces an $\mathrm{R}_{\mathrm{UH}}$ that is $85 \%$ of $\mathrm{R}_{\mathrm{UHm}}$. The corresponding $\mathrm{C}_{\mathrm{crt}} \mathrm{s}$ for the various

3 conditions are presented in Table 2. While the range of $\mathrm{C}_{\mathrm{crt}}$ varies from $0.8 \mathrm{M}$ to $4.25 \mathrm{M}$, the

$4 \quad \mathrm{C}_{\mathrm{Crt}}$ is lowest in case of $S$. pasteurii cells, cultured in BHI harvested by centrifugation $(0.8 \mathrm{M})$

5 and, the $\mathrm{C}_{\mathrm{crt}}$ is highest in case of S. pasteurii cells grown in $\mathrm{BHI}$ and harvested by vacuum

6 filtration (4.25M). An optimal concentration of urea would be equal to or less than $\mathrm{C}_{\mathrm{Crt}}$ and

7 from Fig. 3 (a), (b) and (c), it can be observed that the UH appears to be stable at $1 \mathrm{M}$ urea for

8 all cases except for $S$. pasteurii cells harvested by vacuum filtration, where the optimal

9 concentration appears to be at $1.75 \mathrm{M}$. Further optimisation or the process is to be carried out

10 based on the factors discussed earlier i.e., time required for $\mathrm{CaCO}_{3}$ precipitation and the

11 extent of precipitation to be achieved.

12 However, it should be realized that treating large volumes of soil, in real life 13 situations, would be extremely expensive when BHI/LB/any other commercially available 14 nutrient media, that are normally employed for laboratory-scale experiments. Hence, an 15 alternate source of nutrients for culturing microbial cells in large volumes without 16 compromising on their urease activity should be explored. It should also be borne in mind 17 that such alternate nutrient media should be environmentally friendly, directly injectable into 18 the soil.

\section{SELECTION OF THE APPROPRIATE $p H$ BUFFER}

21 Using previously optimized conditions, urease activity of microbial cells and variation 22 of $\mathrm{pH}$ of the UHM were monitored over time in different buffer media: combination of 23 ammonium chloride and sodium bicarbonate, sodium acetate and Tris 24 [tris(hydroxymethyl)aminomethane], an organic buffer solution (Fig. 5). 
1 The urease activities were measured in the form of EC (Fig. 5b) in different buffer

2 media. The orders of timing, by which reactions reached $\mathrm{pH} 8.5$, were as follows: tap water, 3 acetate $(0.1 \mathrm{M})$, PBS, Tris $(0.01 \mathrm{M})$, acetate $(1 \mathrm{M})$, ammonium chloride and sodium

4 bicarbonate, and Tris $(0.1 \mathrm{M})$. The first two buffers had elevated $\mathrm{pH}$ at start of reactions,

5 which may have contributing to their timings, but still have relatively immediate effect (based

6 on experience). Interestingly, increasing the buffering capacity of the system, especially with

7 organic buffer (e.g., Tris), delays the onset of calcite precipitation by increasing the amount

8 of urea that must be hydrolysed before there is a sufficient $\mathrm{pH}$ increase to trigger $\mathrm{CaCO}_{3}$

9 supersaturation.

10 Incidentally, the most suitable buffer will be selected based on the desired time for $\mathrm{pH}$

11 to become 8.5, as depicted in Fig. 5 (a), which highlights the amount of time for reactions to 12 reach critical $\mathrm{pH}$ 8.5. As mentioned previously (in the introduction), treatment time depends 13 on the permeability and volume of soil to be treated. However, it should be reminded that the 14 absence of buffer causes instantaneous rise in $\mathrm{pH}$ of the UHM, which leads to instantaneous 15 calcite precipitation and/or clogging of flow paths. In the presence of a buffer, care should be 16 taken so that the rise in $\mathrm{pH}$ does not get too delayed, which might result in the use of 17 excessive reagents. By varying the buffer used, the time for precipitation of $\mathrm{CaCO}_{3}$ to occur 18 could be controlled from 16 minutes (10mM Tris) to $80 \mathrm{mins}$ (100mM Tris) for a UHM of $1 \mathrm{M}$ 19 Urea and $1.0 \mathrm{OD}_{600}$ bacteria. This indicates that the MICP process can be tailored to site 20 specific and application specific scenarios.

21 Further, it should be realized that when any fluid interacts with the soil, its $\mathrm{pH}$ varies 22 depending upon the chemical characteristics, and in particular $\mathrm{pH}$, of the soil, as depicted in 23 Fig. 6. It is observed that UHM gets buffered by the soil extracts unlike the tap water where 24 no buffering action was observed. However, buffering of $\mathrm{pH}$, due to influence of soil, does 25 not provide any significant delay in the rise in $\mathrm{pH}$ unlike most other buffers considered in this 
1 study. Among the five soils considered, the critical $\mathrm{pH}$, equal to 8.5 , was attained in all the

2 cases within 15 minutes, a time which is less than the time taken by the other buffers except

3 for $0.1 \mathrm{M} \mathrm{CH}_{3} \mathrm{COONa}$. This indicates that even though the soil buffering action influences the

4 rise in $\mathrm{pH}$ of the $\mathrm{UHM}$, the significance of such a buffering action from a practical point of

5 view is debatable.

6 From a field application perspective, cementing reagents (the mixture of urea and

7 calcium source) could be mixed with the buffer medium instead of water and injected in to

8 the ground. Another way of achieving this, but, with limited efficiency, would be to inject a

9 known volume of buffer in to the ground prior to injection of the bacterial suspension or the

10 cementing reagents. However, such an exercise needs to be simulated in the laboratory

11 conditions prior to field implementation.

12 TIME REQUIRED FOR COMPLETE UREA HYDROLYSIS

13 Urea hydrolysis decreases with time exponentially, reaching a residual activity level,

14 which remains constant as the reaction progresses. This residual activity continues so long as

15 urea remains present in the system. The time required for complete hydrolysis of urea is of

16 prime importance in applying this methodology for geomaterials either in the laboratory or in

17 the field. An optimal time interval between successive treatments to the geomaterials would

18 be the time required for complete hydrolysis of urea, as complete utilisation of urea is key to

19 reduce or minimise the intermixing of urea with the ground water in the geoenvironment.

20 Any additional time interval is unwarranted for as it delays the process with no progress

21 towards the desired outcome. The residual activity for $1 \mathrm{OD}_{600}$ bacteria in case of $1 \mathrm{M}$

22 concentration of urea is $2.5 \mathrm{mM} / \mathrm{min} / \mathrm{OD}$. Considering this as the rate of the reaction for

23 complete hydrolysis of urea, the time required would be 6 hours.

24 However, when a geomaterial is being treated, the amount of microbial cells retained

25 in the matrix of geomaterial plays an important role on the time required for full utilization of 
1

2

3

4

5

6

7

8

9

10

1 urea. The retention of microbial cells inside a porous media depends on several other factors

2 such as the advective force of the fluids flowing through the matrix, the sorption

3 characteristics of geomaterials and microbial cells, the physiology of the cells when it comes

4 in contact with the geomaterials and so on. Considering various retention percentages within

5 a control volume, a theoretical estimate of the time required for complete urea hydrolysis has

6 been presented in Fig. 7. Further studies are necessary to understand the phenomena on 7 microbial retention in a porous media. 


\section{Conclusions}

2 Calcite precipitation by urea hydrolysis through urease enzyme, a biochemical 3 process, offers a technique for improving the engineering properties of soils and other 4 construction materials. Though several studies reported this technique as a promising 5 technique for sustainable construction, materials and technologies, there is an absence of a 6 standard protocol for selection of urease source, growth of microbial cells, harvesting of 7 microbial cells, and for mix proportioning and performance assessment of calcite 8 precipitation. To date geotechnical studies have focused on reporting geomaterial and porous 9 media characteristics, rather than the biochemical and microbiology influences.

10 Crossing disciplinary borders to delineate the biochemical influence of geomaterial 11 process, this study presents a strategy for optimising urea hydrolysis. Ureolytic activity has 12 been shown to be affected by the nutrient media in which the cells have been cultured. While 13 the study highlights that methodology employed for harvesting of cells does not affect the 14 ureolytic activity of the cells, the yield of active cells from filtration is about $25 \%$ less than 15 compared to centrifugation, as explained in this paper, and can significantly affect the cost 16 efficiency of the project. Further, optimal urea concentration was found to vary from $1 \mathrm{M}$ to

$171.75 \mathrm{M}$ for the cases considered in this study. It should be noticed that, any further increase in 18 urea concentration would not result in better ureolytic activity. These optimal parameters, 19 though, they serve as a guiding formula for calcite precipitation studies, need to be further 20 validated with a larger spectrum of variables involved during employing urea hydrolysis in 21 calcite precipitation systems. 


\section{Acknowledgments}

2 The authors wish to acknowledge the support of the European Commission via the Marie

3 Curie IRSES project GREAT 'Geotechnical and geological Responses to climate change:

4 Exchanging Approaches and Technologies on a world-wide scale' (FP7-PEOPLE-2013-

5 IRSES-612665). 
1 References

2 [1] Ou, C.-Y., Wu, T.-S., and Hsieh, H.-S., "Analysis of Deep Excavation with Column

Type of Ground Improvement in Soft Clay." Journal of Geotechnical Engineering, Vol. 122, No. 9, 1996, pp. 709-716, http://dx.doi.org/10.1061/(ASCE)07339410(1996)122:9(709)

[2] Bergado, D. T., Anderson, L. R., Miura, N., and Balasubramaniam, A. S. 1996. Soft Ground Improvement in Lowland and Other Environments. ASCE, New York.

[3] Zayyat, M. M., Jackson, A. W., Tanaka, T., Hino, T., and Matsuba, Y. (2005). Foundation Soil Improvement Using Vibro Compaction Combined with Geo Grids. Paper presented at the Innovations in Grouting and Soil Improvement.

[4] Horpibulsuk, S., Miura, N., Koga, H., and Nagaraj, T. S., "Analysis of Strength Development in Deep Mixing: A Field Study." Ground Improvement Vol. 8, No. 2, 2004, pp. 59-68, http://dx.doi.org/10.1680/grim.2004.8.2.59

[5] Jayanthi, P. N., and Singh, D. N., "Utilization of Sustainable Materials for Soil Stabilization: State-of-the-Art." Advances in Civil Engineering Materials, Vol. 5, No. 1, 2016, pp. 46-79, http://dx.doi.org/https://doi.org/10.1520/ACEM20150013

[6] Dejong, J. T., Soga, K., Kavazanj Ian, E., Burns, S., Van Paassen, L. A., Al-Qabany, A., . . . Weaver, T., "Biogeochemical Processes and Geotechnical Applications: Progress, Opportunities and Challenges." Geotechnique, Vol. 63, No. 4, 2013, pp. 287-301, http://dx.doi.org/10.1680/geot.SIP13.P.017

[7] Francesca Cappitelli, Lucia Toniolo, Sansonetti, A., Gulotta, D., Ranalli, G., Zanardini, E., and Sorlini, C., "Advantages of Using Microbial Technology over Traditional Chemical Technology in Removal of Black Crusts from Stone Surfaces of Historical Monuments." Applied and Environmental Microbiology, Vol. 73, No. 17, 2007, pp. 5671-5675, http://dx.doi.org/10.1128/AEM.00394-07 
1 [8] Seifan, M., Samani, A. K., and Berenjian, A., "Bioconcrete: Next Generation of SelfHealing Concrete." Appl Microbiol Biotechnol Vol. 100, 2016, pp. 2591-2602, http://dx.doi.org/10.1007/s00253-016-7316-Z

[9] Ivanov, V., and Chu, J., "Applications of Microorganisms to Geotechnical Engineering for Bioclogging and Biocementation of Soil in Situ." Rev Environ Sci Biotechnol Vol. 7, 2008, pp. 139-153, http://dx.doi.org/10.1007/s11157-007-9126-3

[10] DeJong, J. T., Mortensen, B. M., Martinez, B. C., and Nelson, D. C., "Bio-Mediated Soil Improvement." Ecological Engineering, Vol. 36, No. 2, 2010, pp. 197-210, http://dx.doi.org/10.1016/j.ecoleng.2008.12.029

[11] Montoya, B. M., Dejong, J. T., and Boulanger, R. W., "Dynamic Response of Liquefiable Sand Improved by Microbial-Induced Calcite Precipitation." Geotechnique, Vol. 63, No. 4, 2013, pp. 302-312, http://dx.doi.org/[http://dx.doi.org/10.1680/geot.SIP13.P.019]

[12] McCarthy, T. S., Ellery, W. N., and Ellery, K., "Vegetation-Induced, Subsurface Precipitation of Carbonate as an Aggradational Process in the Permanent Swamps of the Okavango (Delta) Fan, Botswana." Chemical Geology, Vol. 107, 1993, pp. 111131

[13] Park, S.-S., Choi, S.-G., and Nam, I.-H., "Effect of Plant-Induced Calcite Precipitation on the Strength of Sand." J. Mater. Civ. Eng., Vol. 26, No. 8, 2014, pp. 06014017(06014011-06014015), $\quad$ http://dx.doi.org/10.1061/(ASCE)MT.1943$\underline{5533.0001029}$

[14] Dilrukshi, R. A. N., and Kawasaki, S., "Effective Use of Plant-Derived Urease in the Field of Geoenvironmental/ Geotechnical Engineering." Journal of Civil \& Environmental Engineering, Vol. 6, No. 1, 2016, pp. 207, http://dx.doi.org/10.4172/2165-784X.1000207 
1 [15] Dilrukshi, R. A. N., and Kawasaki, S., "Plant-Derived Urease Induced Sand 2 Cementation Used in Geotechnical Engineering Applications", presented at the 3 International Conference on Geomechanics, Geo-energy and Geo-resources, 4 Melbourne, Australia.,28-29 September, 2016, pp.,

5 [16] Johnson, K. A., and Goody, R. S., "The Original Michaelis Constant: Translation of 6 the 1913 Michaelis-Menten Paper." Biochemistry, Vol. 50, No. 39, 2011, pp. 82648269, http://dx.doi.org/10.1021/bi201284u

[17] Mitchell, A. C., and Ferris, F. G., "The Coprecipitation of Sr into Calcite Precipitates Induced by Bacterial Ureolysis in Artificial Groundwater: Temperature and Kinetic Dependence." Geochimica Et Cosmochimica Acta, Vol. 69, No. 17, 2005, pp. 41994210, http://dx.doi.org/10.1016/j.gca.2005.03.014

[18] DeJong, J. T., Fritzges, M. B., and Nüsslein, K., "Microbially Induced Cementation to Control Sand Response to Undrained Shear." Journal of Geotechnical and Geoenvironmental Engineering, Vol. 132, No. 11, 2006, pp. 1381-1392, http://dx.doi.org/10.1061/(ASCE)1090-0241(2006)132:11(1381)

[19] Whiffin, V. S., van Paassen, L. A., and Harkes, M. P., "Microbial Carbonate Precipitation as a Soil Improvement Technique." Geomicrobiology Journal, Vol. 24, No. 5, 2007, pp. 417-423, http://dx.doi.org/10.1080/01490450701436505

[20] Fujita, Y., Taylor, J. L., Gresham, T. L. T., Delwiche, M. E., Colwel, F. S., Mcling, T. L., . . Smith, R. W., "Stimulation of Microbial Urea Hydrolysis in Groundwater to Enhance Calcite Precipitation." Environmental Science Technology, Vol. 42, No. 8, 2008, pp. 3025-3032, http://dx.doi.org/10.1021/es702643g

[21] Martinez, B. C., and DeJong, J. T., "Bio-Mediated Soil Improvement: Load Transfer Mechanisms at the Micro- and Macro-Scales", presented at the Advances in Ground 
1 Improvement: US-China Workshop on Ground Improvement Technologies, 2009, $2 \quad$ ASCE, pp. 242-251,

3 [22] Harkes, M. P., van Paassen, L. A., Booster, J. L., Whiffin, V. S., and van Loosdrecht, 4 M. C. M., "Fixation and Distribution of Bacterial Activity in Sand to Induce $5 \quad$ Carbonate Precipitation for Ground Reinforcement." Ecological Engineering, Vol. 36, No. 2, 2010, pp. 112-117, http://dx.doi.org/10.1016/j.ecoleng.2009.01.004

[23] Tobler, D. J., Cuthbert, M. O., Greswell, R. B., Riley, M. S., Renshaw, J. C., Handley-Sidhu, S., and Phoenix, V. R., "Comparison of Rates of Ureolysis between Sporosarcina Pasteurii and an Indigenous Groundwater Community under Conditions Required to Precipitate Large Volumes of Calcite." Geochimica Et Cosmochimica Acta, Vol. 75, No. 11, 2011, pp. 3290-3301, http://dx.doi.org/10.1016/j.gca.2011.03.023

[24] Cheng, L., and Cord-Ruwisch, R., "In Situ Soil Cementation with Ureolytic Bacteria by Surface Percolation." Ecological Engineering, Vol. 42, 2012, pp. 64-72, http://dx.doi.org/10.1016/i.ecoleng.2012.01.013

[25] Cheng, L., Cord-Ruwisch, R., and Shahin, M. A., "Cementation of Sand Soil by Microbially Induced Calcite Precipitation at Various Degrees of Saturation." Canadian Geotechnical Journal, Vol. 50, No. 1, 2013, pp. 81-90, http://dx.doi.org/10.1139/cgj-2012-0023

[26] Lee, L. M., Ng, W. S., Tan, C. K., and Hii, S. L., "Bio-Mediated Soil Improvement under Various Concentrations of Cementation Reagent." Applied Mechanics and Materials, $\quad$ Vol. 204-208, 2012, pp. 326-329, http://dx.doi.org/10.4028/www.scientific.net/AMM.204-208.326 
1 [27] Qabany, A. A., and Soga, K., "Effect of Chemical Treatment Used in Micp on

2 Engineering Properties of Cemented Soils." Geotechnique, Vol. 63, No. 4, 2013, pp. 3 331-339, http://dx.doi.org/10.1680/geot.SIP13.P.022

4 [28] Soon, N. W., Lee, M.-L., and Hii, S.-L., "An Overview of the Factors Affecting 5 Microbial-Induced Calcite Precipitation and Its Potential Application in Soil 6 Improvement." International Journal of civil, environmental, structural, construction and architectural engineering Vol. 6, No. 2, 2012, pp. 188-1954

8 [29] Soon, N. W., Lee, L. M., Khun, T. C., and Ling, H. S., "Improvements in 9 Engineering Properties of Soils through Microbial-Induced Calcite Precipitation." 10 KSCE Journal of Civil Engineering, Vol. 17, No. 4, 2013, pp. 718-728, $11 \quad$ http://dx.doi.org/10.1007/s12205-013-0149-8

12 [30] Hamdan N., Kavazanjian Jr. E., and S., O. D. (2013). Carbonate Cementation Via 13 Plant Derived Urease. Paper presented at the Proceedings of the 18th International 14 Conference on Soil Mechanics and Geotechnical Engineering, Paris.

15 [31] Handley-Sidhu, S., Sham, E., Cuthbert, M. O., Nougarol, S., Mantle, M., Johns, M. 16 L., . . . Renshaw, J. C., "Kinetics of Urease Mediated Calcite Precipitation and 17 Permeability Reduction of Porous Media Evidenced by Magnetic Resonance 18 Imaging." International Journal of Environmental Science and Technology, Vol. 10, No. 5, 2013, pp. 881-890, http://dx.doi.org/10.1007/s13762-013-0241-0

20 [32] Velmourougane, K., Venugopalan, M. V., Bhattacharyya, T., Sarkar, D., Pal, D. K., 21 Sahu, A., . . Tiwary, P., "Urease Activity in Various Agro-Ecological Sub-Regions 22 of Black Soil Regions of India." Proceedings of the National Academy of Sciences 23 India Section B-Biological Sciences, Vol. 83, No. 4, 2013, pp. 513-524, http://dx.doi.org/10.1007/s40011-013-0162-1 
1 [33] Gomez, M. G., Martinez, B. C., DeJong, J. T., Hunt, C. E., deVlaming, L. A., Major,

D. W., and Dworatzek, S. M., "Field-Scale Bio-Cementation Tests to Improve Sands." Proceedings of the Institution of Civil Engineers - Ground Improvement, Vol. 168, No. 3, 2015, pp. 206-216, http://dx.doi.org/10.1680/grim.13.00052

[34] Nemati, M., and Voordouwb, G., "Modification of Porous Media Permeability, Using Calcium Carbonate Produced Enzymatically in Situ." Enzyme and Microbial 


\section{List of Tables}

TABLE 1 A summary of MICP laboratory studies.

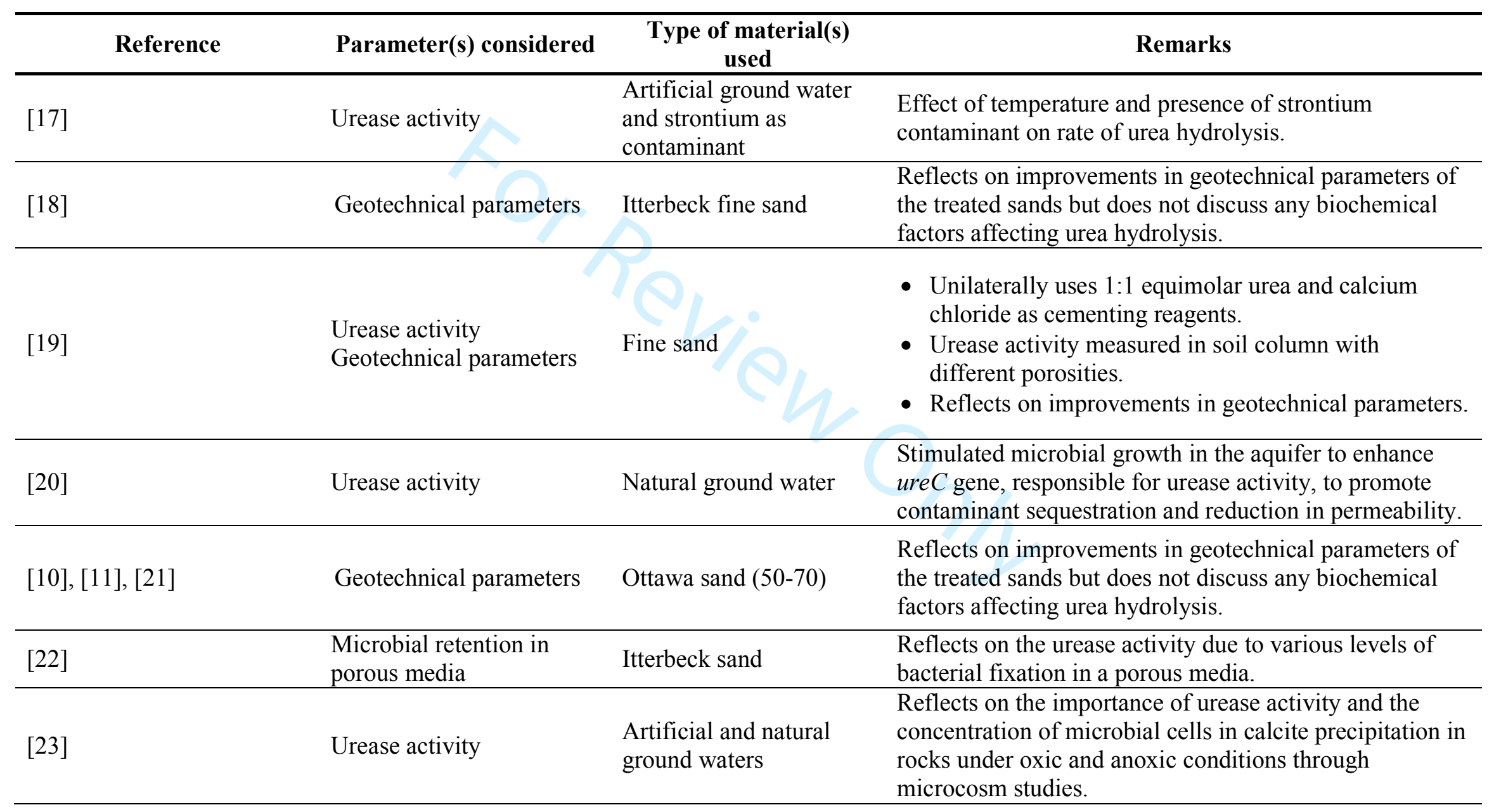




\begin{tabular}{|c|c|c|c|}
\hline$[24],[25]$ & $\begin{array}{l}\text { Urease activity } \\
\text { Geotechnical parameters }\end{array}$ & Fine sand & $\begin{array}{l}\text { Urease activity at } 1.5 \mathrm{M} \text { urea concentration, measured at } \\
\text { different flow conditions in the sand column. }\end{array}$ \\
\hline$[26]$ & Geotechnical parameters & Clayey sand & $\begin{array}{l}\text { Optimised the cementing reagent concentration based on } \\
\text { improvements in geotechnical parameters. Tests } \\
\text { performed at different concentrations of urea in the } \\
\text { presence of a high } \mathrm{OD}_{600}(3.3) \text { bacterial suspension }\end{array}$ \\
\hline [27] & Geotechnical parameters & Fine sand & $\begin{array}{l}\text { Optimised cementing reagent concentration based on } \\
\text { improvements in geotechnical parameters. Tests } \\
\text { performed by varying frequency of injection and } \\
\text { different concentrations of cementing reagents in to the } \\
\text { sand column }\end{array}$ \\
\hline [25] & Geotechnical parameters & $\begin{array}{l}\text { Coarse sand } \\
\text { Fine sand }\end{array}$ & $\begin{array}{l}\text { Measured urease activity of } 1 \mathrm{OD}_{600} \text { bacteria at } 1 \mathrm{M} \text { urea } \\
\text { concentration and used the same for treating the sands }\end{array}$ \\
\hline$[28],[29]$ & Geotechnical parameters & Sandy silt & $\begin{array}{l}\text { Reflects on improvements in geotechnical parameters } \\
\text { and does not discuss any biochemical factors affecting } \\
\text { urea hydrolysis. }\end{array}$ \\
\hline [30] & Geotechnical parameters & $\begin{array}{l}\text { Ottawa } 20-30 \text { and F-60 } \\
\text { sand }\end{array}$ & $\begin{array}{l}\text { Reflects on feasibility of plant source of urease enzyme } \\
\text { for cementation of sands by calcite precipitation. }\end{array}$ \\
\hline [31] & $\begin{array}{l}\text { Urease activity } \\
\text { Geotechnical parameters }\end{array}$ & Borosilicate bead & $\begin{array}{l}\text { Reflects on the urease activity of Canavalia ensiformis, a } \\
\text { plant source of the enzyme. Further, the distribution of } \\
\text { calcium carbonate precipitated in the beads column has } \\
\text { been studied. }\end{array}$ \\
\hline [32] & Urease activity & Field soils & $\begin{array}{l}\text { Investigates urease activity of soils from various parts of } \\
\text { India to assess the availability of nitrogen for } \\
\text { optimisation of fertilizer use in agricultural practices. }\end{array}$ \\
\hline [33] & Geotechnical parameters & Field investigation & $\begin{array}{l}\text { Investigates the potential and performance of MICP for } \\
\text { practical field-scale applications. }\end{array}$ \\
\hline [34] & $\begin{array}{l}\text { Calcite precipitation and } \\
\text { geotechnical parameters }\end{array}$ & $\begin{array}{l}\text { Glass beads and } \\
\text { sandstone }\end{array}$ & $\begin{array}{l}\text { Investigates the kinetics of calcite precipitation and } \\
\text { permeability of enzymatically treated specimens }\end{array}$ \\
\hline
\end{tabular}


1 TABLE 2- $\mathrm{k}_{\mathrm{m}}$ and $\mathrm{R}_{\mathrm{UHm}}$ (analogous to $\mathrm{V}_{\mathrm{max}}$ ) from Lineweaver-Burk transformation plots. The ratio $2 \quad \mathrm{R}_{\mathrm{UHm}} / \mathrm{k}_{\mathrm{m}}$ represent pseudo first-order rate kinetics at low substrate concentrations.

\begin{tabular}{|c|c|c|c|}
\hline & $\mathbf{k}_{\mathrm{m}}{ }^{\mathrm{a}}, \mathbf{M}$ & $\begin{array}{c}R_{\mathrm{UHm}}{ }^{\mathrm{a}}, \\
\mathrm{mS} / \mathrm{cm} / \mathrm{min} \\
\left(\times 10^{-4}\right)\end{array}$ & $\mathbf{R}_{\mathbf{U H m}} / \mathbf{k}_{\mathbf{m}}$ \\
\hline BHI-centrifugation & $\begin{array}{c}0.151 \\
( \pm 0.036)\end{array}$ & $\begin{array}{c}5.57 \\
( \pm 0.28)\end{array}$ & 3.8 \\
\hline BHI-filtration & $\begin{array}{c}0.880 \\
( \pm 0.249) \\
\end{array}$ & $\begin{array}{c}7.7 \\
( \pm 0.99) \\
\end{array}$ & 0.9 \\
\hline LB-centrifugation & $\begin{array}{c}0.273 \\
( \pm 0.038) \\
\end{array}$ & $\begin{array}{c}3.52 \\
( \pm 0.14) \\
\end{array}$ & 1.3 \\
\hline JBM & $\begin{array}{c}0.42 \\
( \pm 0.045)\end{array}$ & $\begin{array}{c}7.10 \\
( \pm 0.33)\end{array}$ & 1.9 \\
\hline
\end{tabular}

3

${ }^{a}$ values in parenthesis indicates the statistical range

4

5 
TABLE 3- Relative performance matrix of different UHMs used in the study.

\begin{tabular}{|c|c|c|c|c|}
\hline \multicolumn{5}{|c|}{$\mathrm{k}_{\mathrm{m}}$} \\
\hline & LB & JBM & BHI-Fil & BHI-Cent \\
\hline LB & - & 50.75 & 166.01 & -48.37 \\
\hline JBM & -- & - & 76.46 & -65.75 \\
\hline BHI-Fil & - & - & - & -80.59 \\
\hline BHI-Cent & - & - & - & - \\
\hline \multicolumn{5}{|c|}{$\mathrm{R}_{\mathrm{UHm}}$} \\
\hline & LB & $\overline{\mathrm{JBM}}$ & BHI-Fil & BHI-Cent \\
\hline LB & - & 131.87 & 95.57 & 55.06 \\
\hline JBM & - & - & -15.65 & -33.13 \\
\hline BHI-Fil & - & - & - & -20.72 \\
\hline BHI-Cent & - & - & - & - \\
\hline
\end{tabular}

2 


\section{Figure Captions}

2 FIG. 1- Different parameters considered for urea hydrolysis.

3 FIG. 2- Urease activity of UHM (a) BHI-centrifugation, (b) BHI-filtration, (c) LB, (d) Jack

4 Bean meal extracts.

5 FIG. 3- Rate of UH ( $\left.\mathrm{R}_{\mathrm{UH}}\right)$ of (a) Sporosarcina pasteurii cells cultured in BHI, (b)

6 Sporosarcina pasteurii cells, cultured in BHI and LB nutrient medium, both harvested by

7 centrifugation, (c) Sporosarcina pasteurii cells (BHI/centrifuged) and Jack bean meal extracts.

8 FIG. 4- Lineweaver-Burk plots for different UHMs considered in the study.

9 FIG. 5- Variation in $\mathrm{pH}(\mathrm{a})$ and $\mathrm{EC}$ (b) duringurea hydrolysis with different buffers $\left(\mathrm{C}_{\mathrm{urea}}=\right.$ $10 \quad 1 \mathrm{M})$

11 FIG. 6- Variation in $\mathrm{pH}$ during urea hydrolysis with different soil extracts $\left(\mathrm{C}_{\text {urea }}=1 \mathrm{M}\right)$.

12 FIG. 7- Time required for complete urea hydrolysis with varying bacterial retention. 


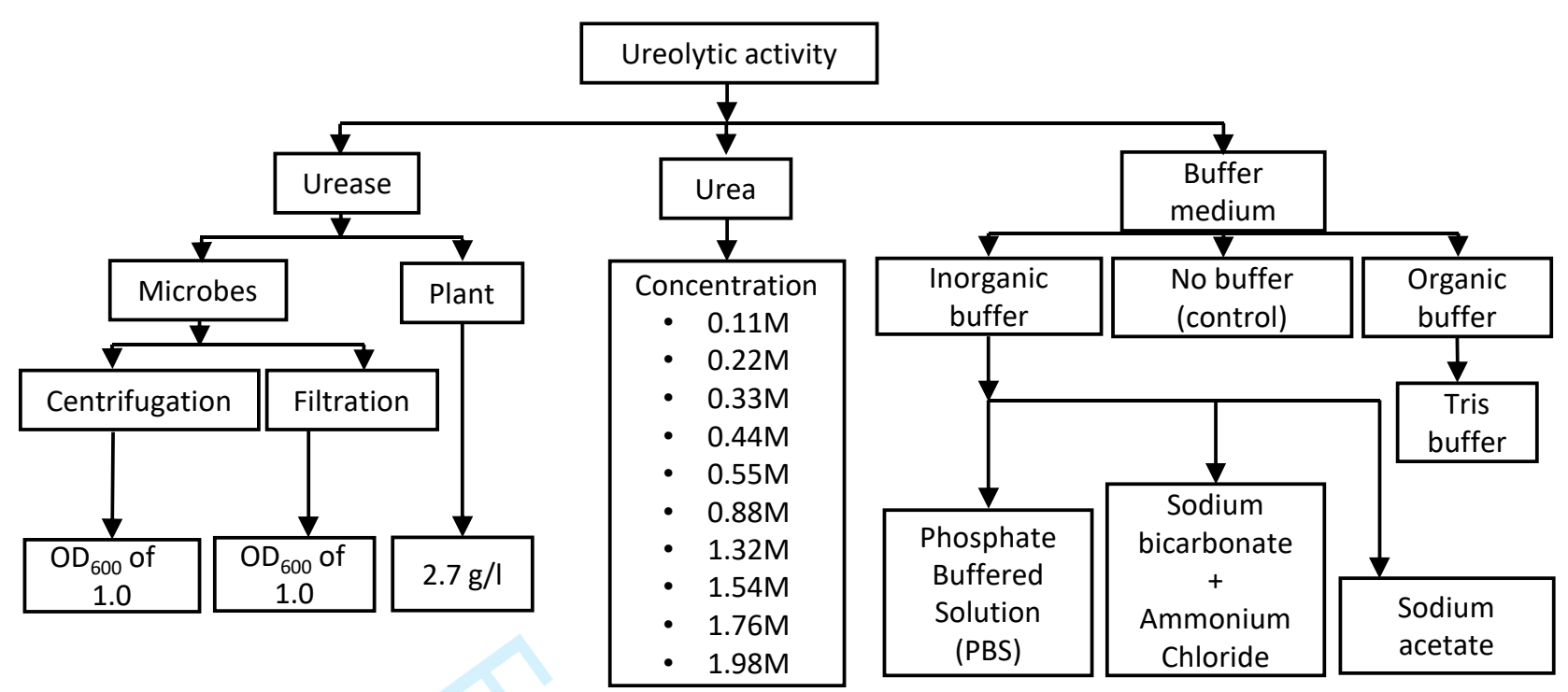



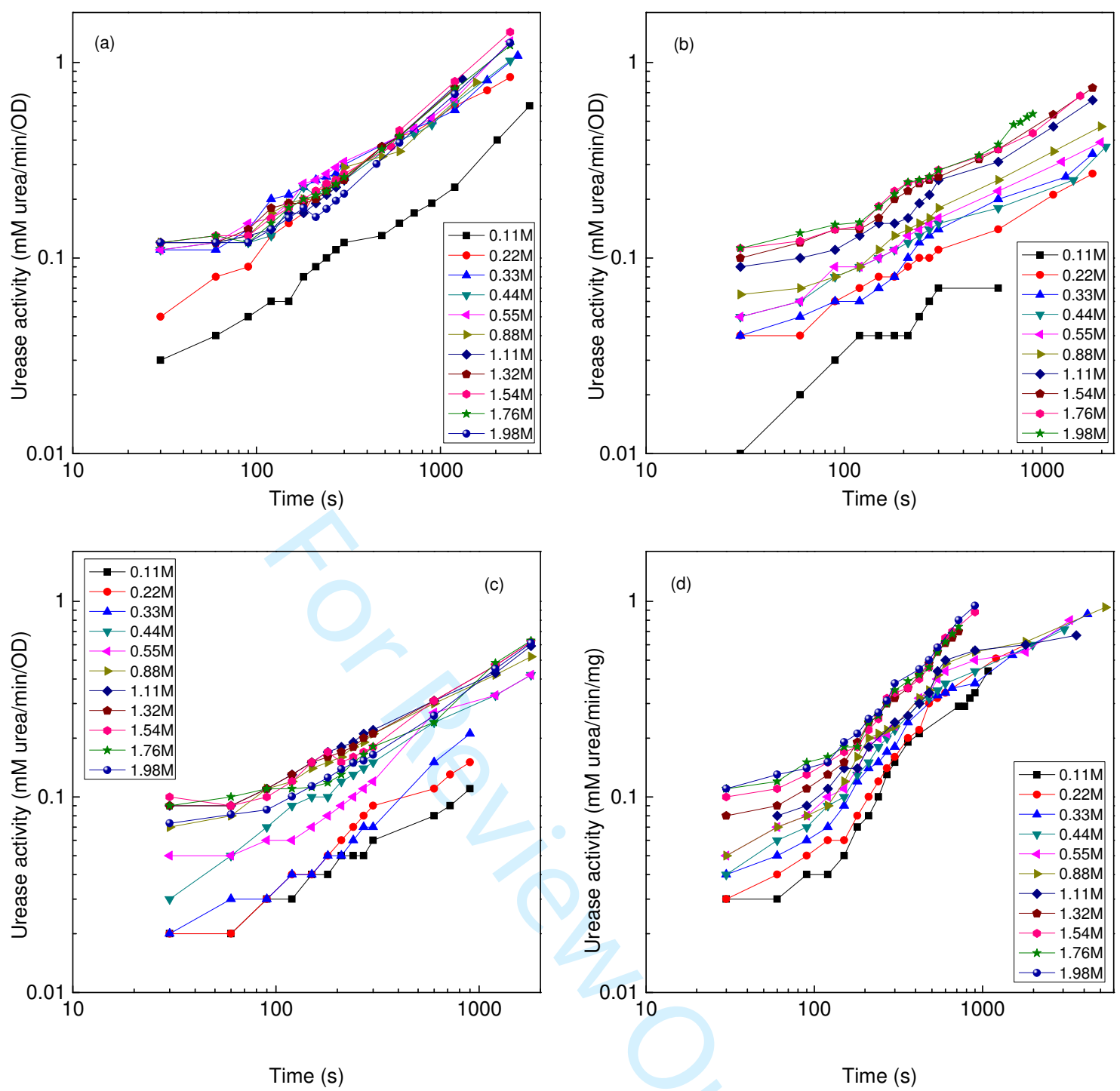

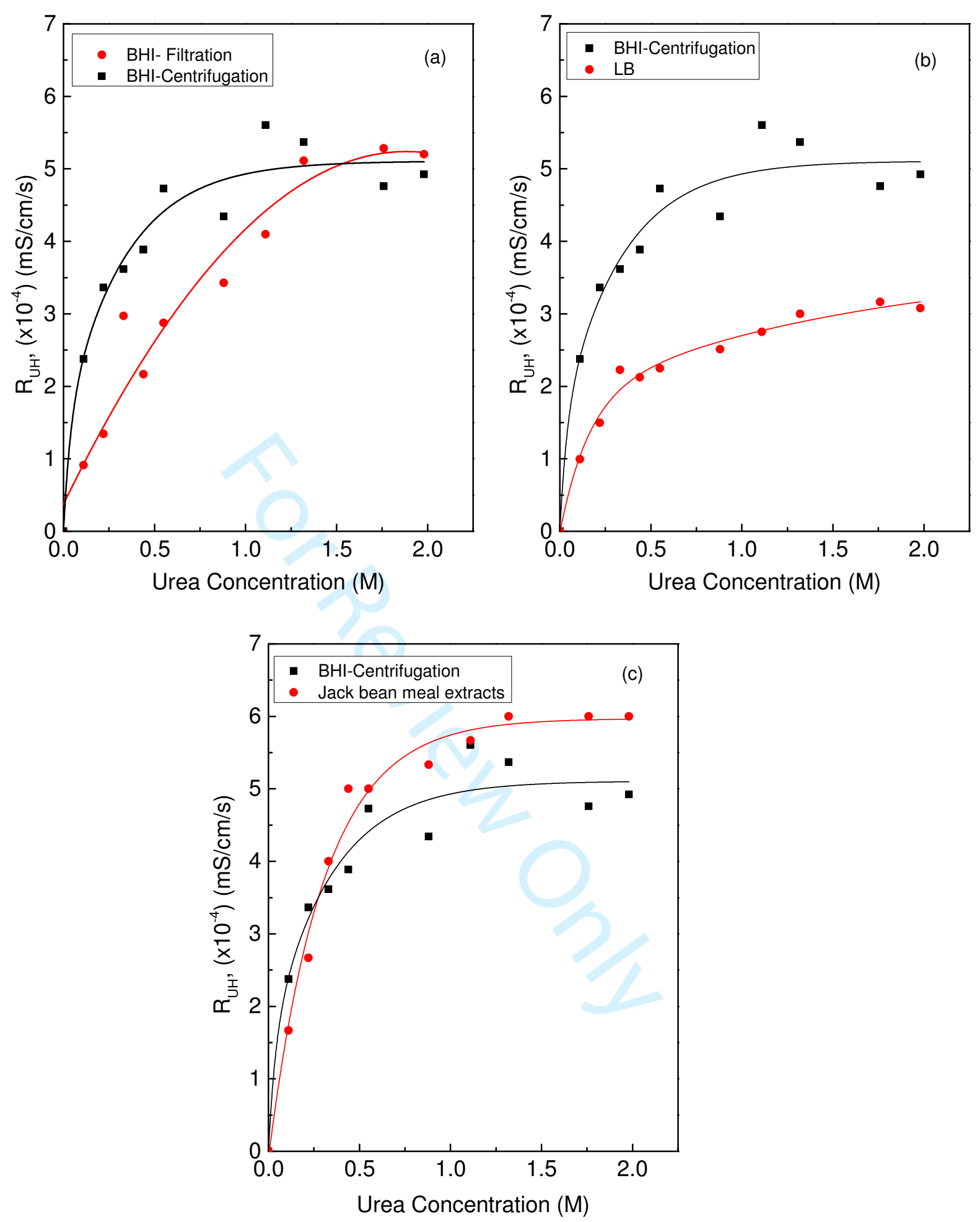


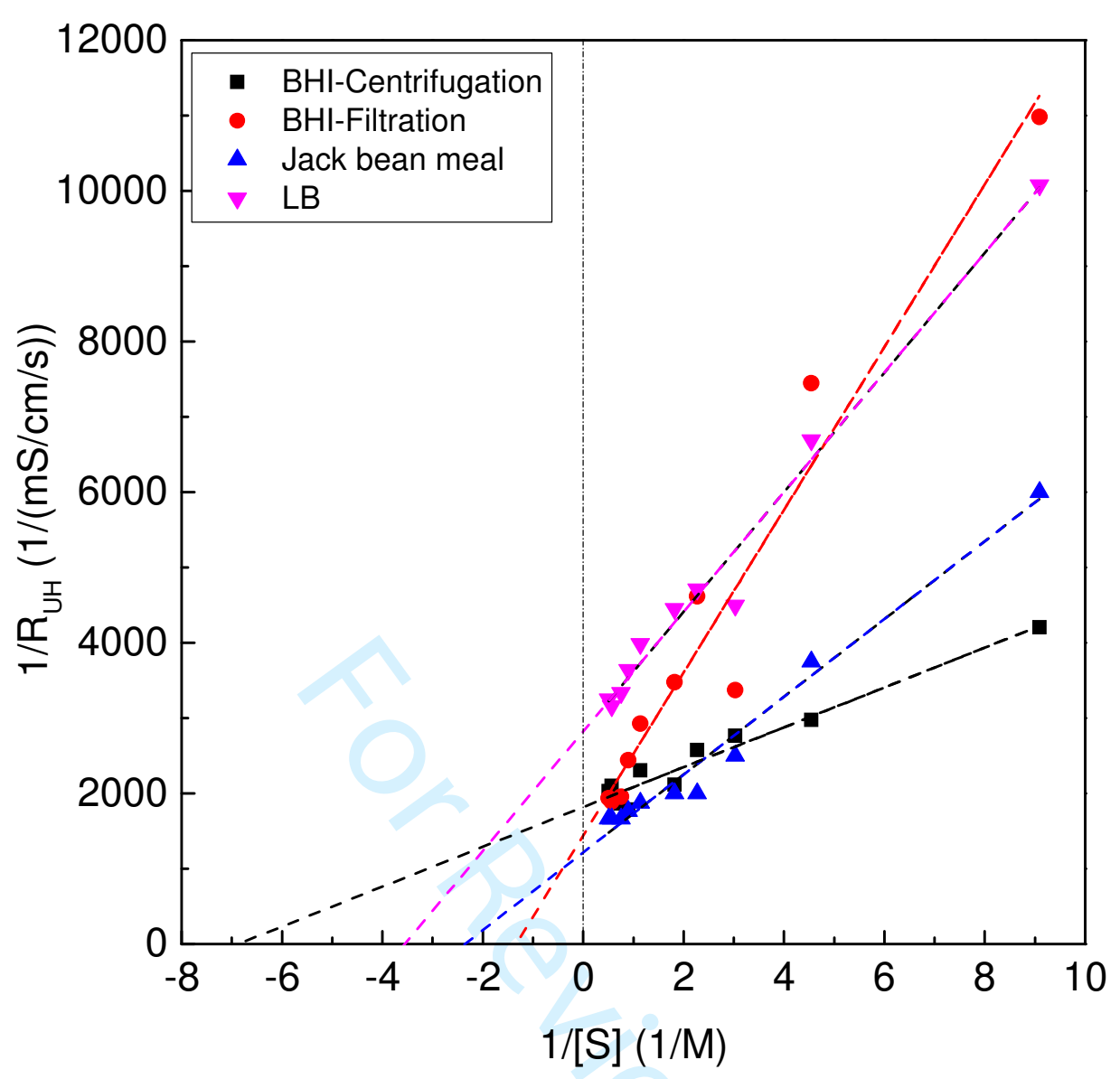



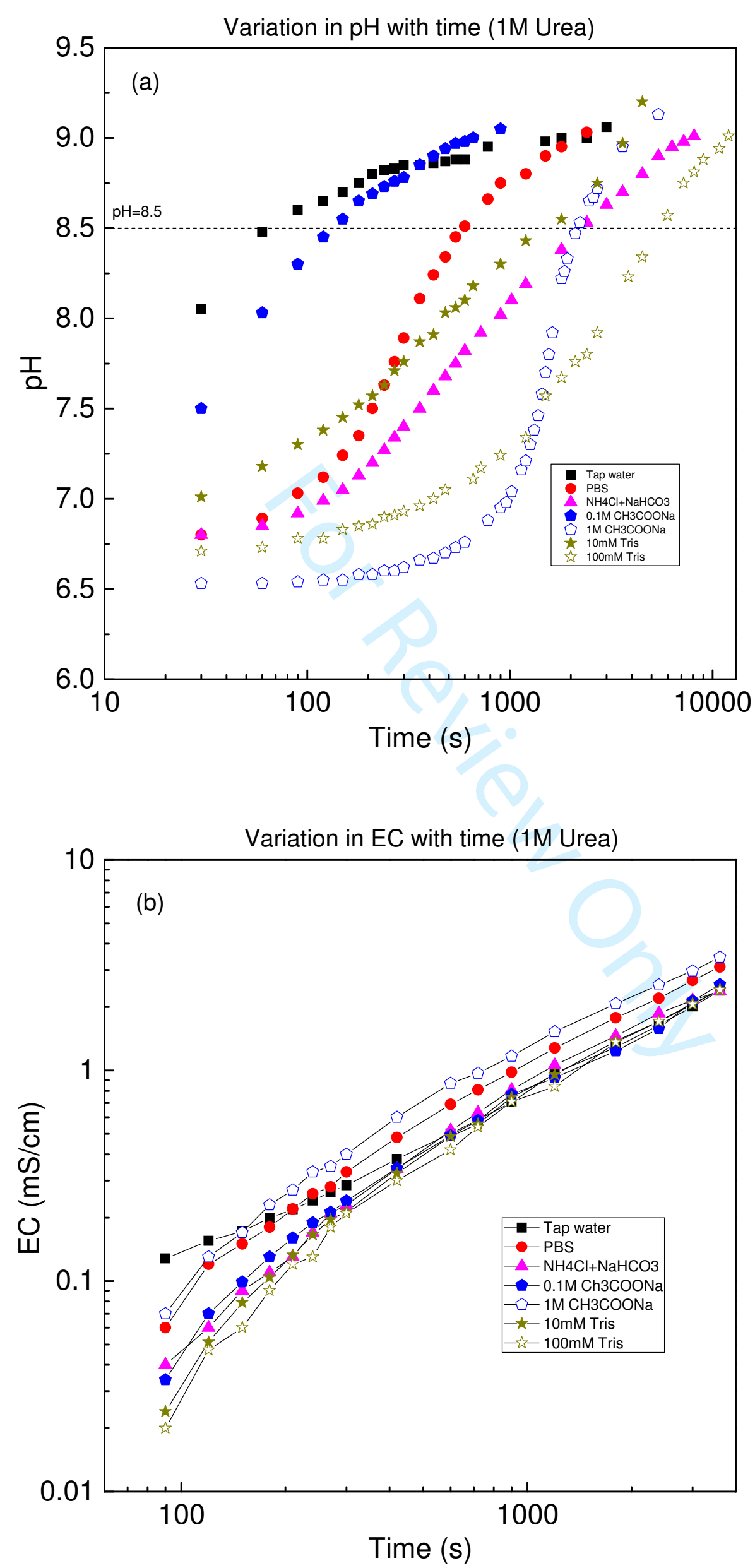


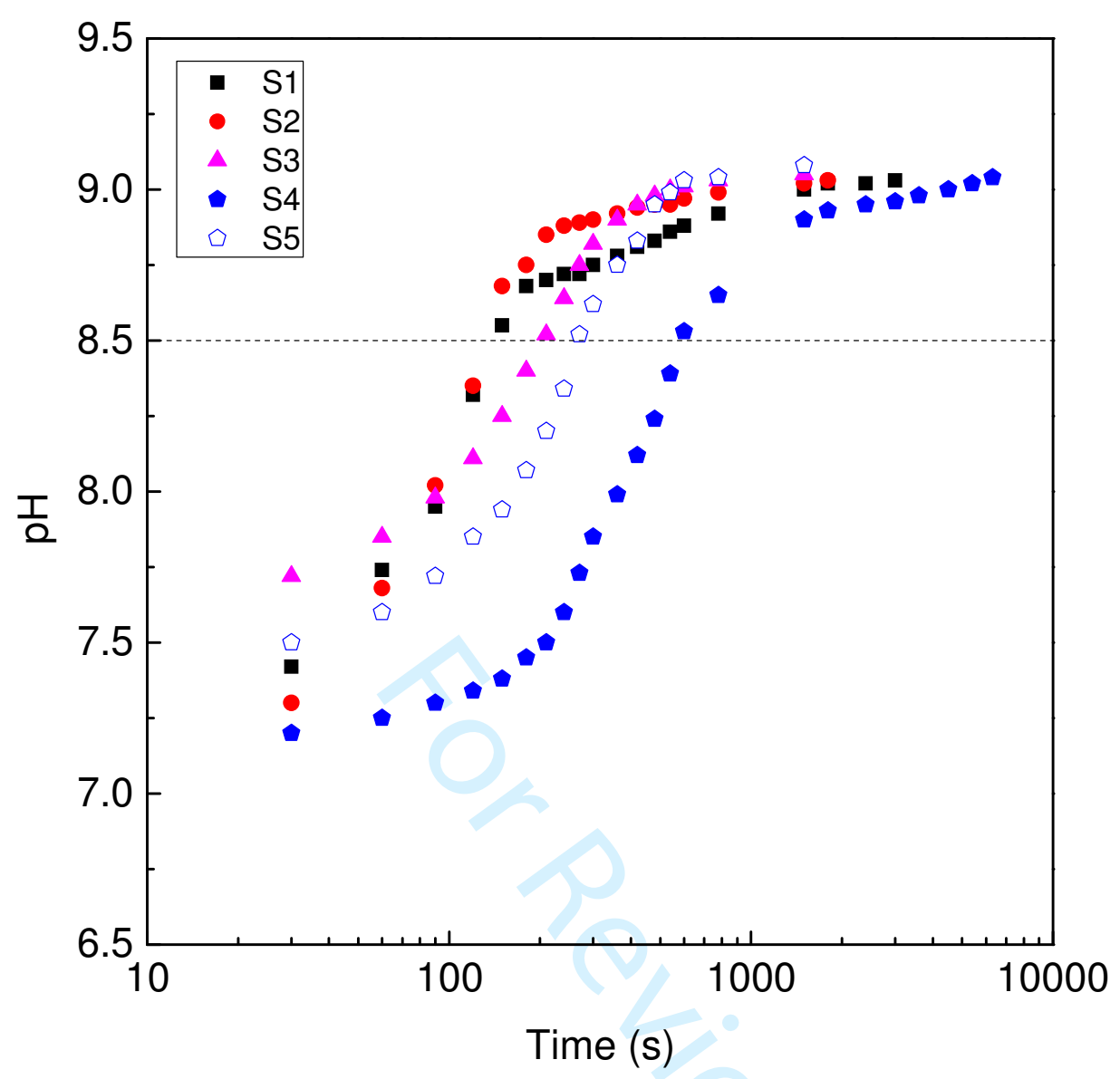




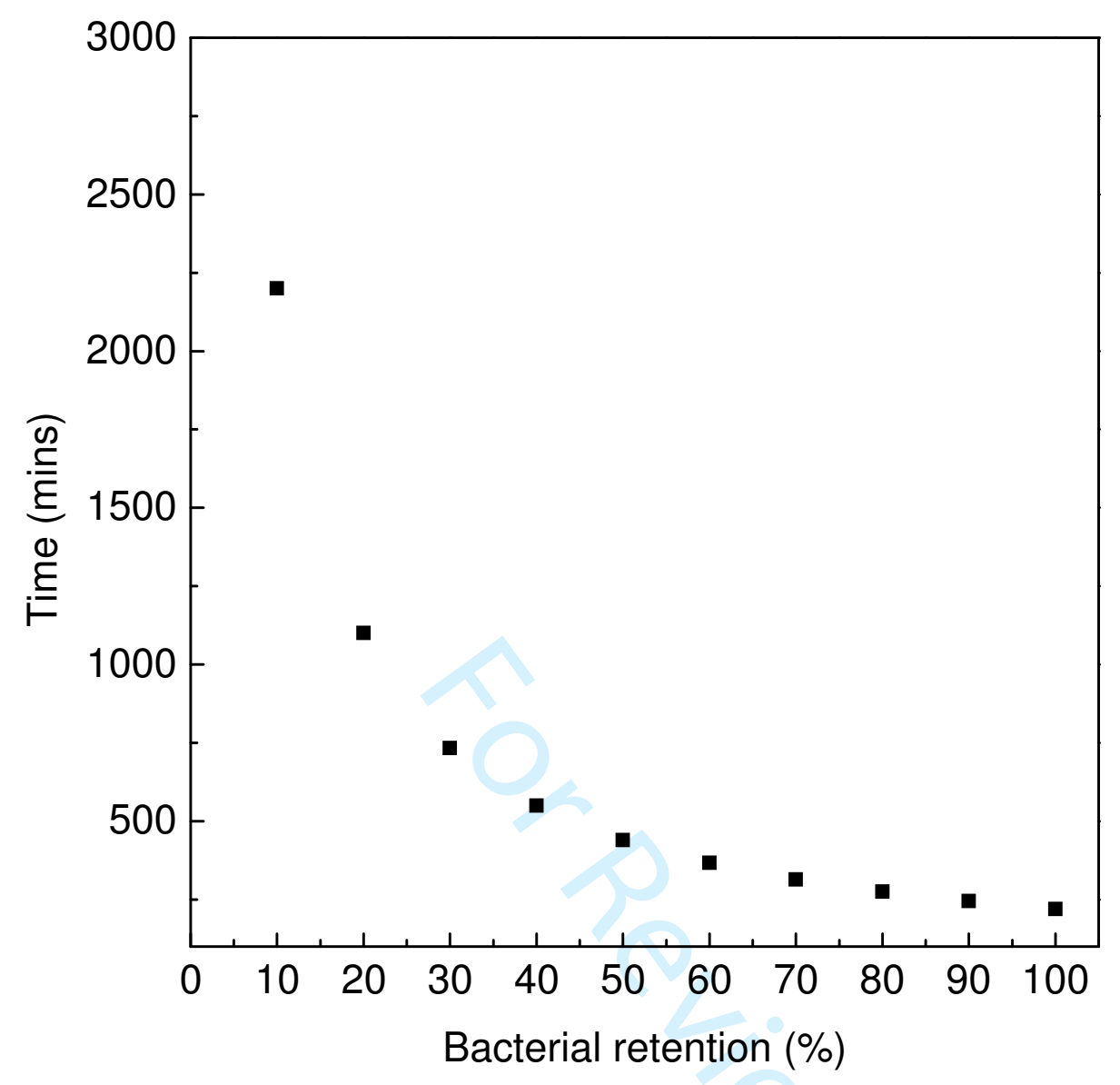

https://mc04.manuscriptcentral.com/astm-jote 